\title{
COMPRESSION PROPERTIES OF KNITTED FABRICS PRINTED BY SUBLIMATION TRANSFER PRINTING TECHNIQUE
}

Sandra Stojanović ${ }^{*}$, Jelka Geršak², Dušan Trajković ${ }^{1}$

\footnotetext{
${ }^{1}$ University of Niš, The Faculty of Technology, Leskovac, Serbia

2 Research and Innovation Centre for Design and Clothing Engineering, Faculty of Mechanical Engineering, University of Maribor Maribor, Slovenia
}

Compression properties of textile materials are useful for determining fullness, softness, smoothness, and stiffness. In addition, compression parameters have significant influence on fabric hand value and quality of textile materials. The present paper reports a study of the sublimation printing process influence on the change in compression properties of knitted fabrics (polyester, cotton, and cotton/ polyester) intended for sportswear manufacturing. For that purpose, the KES-FB3A Compression Tester was used for measuring compression parameters of knitted fabrics. The parameters, which contributed to the smallest reduction percentage in compression properties of polyester knitted fabrics were yarn linear density and weight. For cotton-rich knitted fabrics sublimation coating powder was used for paper modification to bond disperse dyes to cotton fibres. The analysis of the results showed that the printing process had a smaller influence on the change of compression parameters of polyesters in relation to cotton and cotton/polyester knitted fabrics. It was noted that the printing process had the effect of thickness reduction for all knitted fabrics to varying degrees. Printing process contributed to small decrease in compressibility and specific volume values for polyester knitted fabrics. The modification process contributed to the significant reduction of the compressibility for cotton (from $34.46 \%$ to $47.89 \%$ ) and cotton/polyester (from $38.81 \%$ to $50.75 \%$ ) knitted fabrics. In addition, reduction in specific volume values range from $41.86 \%$ to $44.19 \%$ for cotton and from $42.37 \%$ to $45.75 \%$ for cotton/ polyester knitted fabrics was notted.
(ORIGINAL SCIENTIFIC PAPER)

UDC 677.075:677.027.55

DOI 10.5937/savteh2101046S

Keywords: Knitted fabrics, compression properties, sublimation printing, modification process, cotton, and polyester

\section{Introduction}

Compression properties describe the behaviour of a material under a compressive load that acts perpendicular to the textile material, as opposed to a tensile load (also known as transverse or longitudinal compression) [1]. In addition, compression may be defined as a decrease of the intrinsic thickness (space occupied by a textile material subjected to hardly observable pressure) with an appropriate increase in pressure [2]. Compression properties are related to textile material structure, surface properties, as well as compression and structural properties of fibres and yarns [3]. It was established that knitted structures have much higher fabric stretch and percentage of recovery than woven fabrics due to their less compact structure, while woven fabrics possess higher compression properties [4]. Compression values of the knitted fabrics decreased with knit density. This can be explained by a structure of loops, which leads to decreasing compression resilience, and compression energy as the loop space becomes smaller [3]. In addition, the factors that influence knitted fabric's compressibility are structural parameters, loop length and cover factor as well as raw material and fibres blend ratio [5-7].
Compression behaviour of knitted fabrics indicates its resilience and fullness. In addition, compression properties are important factors in determining comfort and fabric hand [8] and have significant influence on garment appearance quality [9]. Textile materials, which compress easily, can be evaluated as soft, possessing high compression values [10].

The compressional energy $(W C)$ represents the energy required for the compression deformation of a textile material. In addition, $W C$ is a measure of compressibility and is related to the thickness of textile material. Thicker fabrics are more compressible. The values of WC primarily affect the total value of fabric hand [1].

The linearity of the curve $F_{k}(h)(L C)$ the compressive stress-strain is a dimensionless parameter that provides information on the nonlinearity of the curve $F_{k}(h)$ from a straight line. The higher the value of the $L C$ parameter, the closer the dependence between the compression load and the deformation is to the linear relationship.

The values of the curve $F_{k}(h)$ depend on the design parameters of the yarn as well as the textile material. In addition, these values affect the quality of the fabric hand feel [1].

\footnotetext{
*Author address: Sandra Stojanović, Faculty of Technology, University of Niš,

Bulevar Oslobodjenja 124, 16000 Leskovac, Serbia.

E-mail: sandra.k770@gmail.com

The manuscript received: 14. 01. 2021.

Paper accepted: 24. 02. 2021.
} 
The compression resilience $(R C)$ is an important parameter that reflects the relationship between the released or reversible energy during stress release recovery and the energy absorbed at compression load. $R C$ is a measure of its volume flexibility. Textile materials with higher $R C$ values give a feeling of elasticity and positively affect the total value of fabric hand [1].

Any modification of textile materials such as pressing, singeing, milling, or printing influence fabrics hand and have a significant impact on the compressibility [2]. For that reason, this paper presents a systematic study of sublimation printing process influence on compression properties of knitted fabrics. The effects of knitted fabrics pattern, yarn, thickness and weight on changes that occurred after the printing process will also be discussed. A better understanding of knitted fabric's compression behaviour may be very useful for improving both basic and industrial knowledge.

\section{Experimental}

For the purpose of investigating sublimation printing process influence on the change in compression properties of knitted fabrics, seven different knitted fabrics were knitted and printed in the CMYK colour model (in four different colours: Cyan, Magenta, Yellow, and Key that is black). Samples of knitted fabrics were tagged in the following manner: Knitted fabrics printed by Cyan ink were tagged with code $C$, followed by the number of knitted fabrics, etc. Unprinted (White) knitted fabrics were tagged with W, followed by the number of knitted fabrics. Structural properties of knitted fabrics are presented in Table 1.

Table 1. Structural parameters of knitted fabrics

\begin{tabular}{|c|c|c|c|c|c|c|c|c|}
\hline $\begin{array}{l}\text { Sample } \\
\text { code }\end{array}$ & Pattern & $\begin{array}{c}\text { Raw } \\
\text { material }\end{array}$ & $\begin{array}{c}\text { Yarn } \\
\text { linear } \\
\text { density } \\
T_{t} \text { (tex) }\end{array}$ & $\begin{array}{l}\text { Horizontal } \\
\text { density } \\
D_{h}\left(\mathrm{~cm}^{-1}\right)\end{array}$ & $\begin{array}{l}\text { Vertical } \\
\text { density } \\
D_{v}\left(\mathrm{~cm}^{-1}\right)\end{array}$ & $\begin{array}{l}\text { Total } \\
\text { density } \\
D_{t}\left(\mathrm{~cm}^{-2}\right)\end{array}$ & $\begin{array}{l}\text { Thickness } \\
h(\mathrm{~mm})\end{array}$ & $\begin{array}{l}\text { Weight } \\
m\left(\mathrm{~g} \mathrm{~m}^{-2}\right)\end{array}$ \\
\hline 01 & Interlock & PES & 7.40 & 16.0 & 21.5 & 344.0 & 0.31 & 124.60 \\
\hline 02 & Interlock & PES & 7.40 & 16.3 & 10.5 & 171.2 & 0.38 & 122.40 \\
\hline 03 & Interlock & PES & $\begin{array}{l}7.04 \\
3.60\end{array}$ & 16.5 & 11.8 & 194.7 & 0.28 & 134.88 \\
\hline 04 & $\begin{array}{c}\text { Pique } \\
\text { (double) }\end{array}$ & $\begin{array}{c}50 \% \\
\text { PES } \\
50 \% \text { Co }\end{array}$ & $\begin{array}{c}7.40 \\
17.35\end{array}$ & 16.0 & 15.9 & 254.4 & 0.67 & 157.60 \\
\hline 05 & $\begin{array}{c}\text { Rib knit } \\
\text { (Honeycomb) }\end{array}$ & PES & 7.40 & 18.7 & 11.3 & 211.3 & 0.50 & 124.18 \\
\hline 06 & Rib knit $1: 1$ & PES & 11.11 & 15.5 & 18.0 & 279.0 & 0.33 & 132.08 \\
\hline 07 & Plain Jersey & Co & 19.46 & 16.0 & 21.5 & 344.0 & 0.43 & 158.32 \\
\hline
\end{tabular}

The thickness of knitted fabrics (Table 1) was determined according to ISO 5084:1996 Standard at a compressive force of $10.02 \pm \mathrm{kPa}$ [11].

The knitted fabrics samples were conditioned and tested in standard atmosphere (temperature of $20 \mathrm{C}^{\circ}$ and $65 \%$ relative humidity during $24 \mathrm{~h}$ ) for conditioning as specified in the ISO 139:2005 Standard [12].

Piezo electronic on-demand inkjet printer model EPSON L1800 was used for paper printing. The print resolution of $7760 \times 1440$ dpi was used. For polyester (PES) knitted fabrics Transfer paper (weight $100 \mathrm{~g} / \mathrm{m}^{2}$ ) Ventus Master 100 by Canapa was used, while, for $\mathrm{Co}$ and $\mathrm{Co} /$ PES knitted fabrics sublimation transfer paper (weight $120 \mathrm{~g} / \mathrm{m}^{2}$ ) High-weight Sublimation Paper by Skyimage was used. Sublisplash (Splashjet-Super-Sub-6C) by
Print Equipment $\mathrm{GmbH}$ \& Co dye sublimation ink was used. The curing process was conducted using Digital High-Pressure Heat Press model SHP-15/20/24LP2MS and pressure was $12 \mathrm{kPa}$. The curing process for PES knitted fabrics was conducted at $185^{\circ} \mathrm{C}$ and the dwell time was 120 seconds and for Co and Co/PES knitted fabrics the process was conducted at $190{ }^{\circ} \mathrm{C}$ and the dwell time was 35 seconds.

For paper modification, in order to bind disperse ink to Co fibres, sublimation coating powder under the trade name Copolymer Thermal Transfer Adhesive Powder, by Shenzhen Tunsing Plastic Products Co., Ltd was used. Sublimation coating powder was applied on paper when the ink was still wet. The average quantity of $1.4 \mathrm{~g}$ of sublimation coating powder was for a $30 \times 30 \mathrm{~cm}$ knitted 
fabric sample. The curing process was carried out after the modification.

A KES-FB3-A compression tester from Kawabata evaluation system (Kato Tech Co. Ltd., Kyoto, Japan), was used for the evaluation of compression properties of unprinted and printed knitted fabrics [13]. The units of compression parameters are original units obtained using the KES-FB3 tester, where the load is expressed as the force per unit length, i.e., the width of the tested sample. The maximum pressure used was $49.035 \mathrm{cN} \mathrm{cm}^{-2}$, while the load speed was $20 \mu \mathrm{m} \mathrm{s}^{-1}$ [1]. The knitted fabrics sample size was $30 \mathrm{~cm} \times 30 \mathrm{~cm}$. Every sample was tested three times and the average values were reported.

There is no linear relationship between the thickness of the textile material $h$ and the compression load $F_{k}$, but the relationship is shown by the following expression:

$h=\frac{k}{\sqrt[3]{F_{k}}}$

where:

$h$ - thickness of textile material [mm],

$k$ - constant proportionality [ $\left.\mathrm{mm}\left(\mathrm{cN} \mathrm{cm}^{-2}\right)^{1 / 3}\right]$,

$F_{k}$ - compression or compression load per unit area [cN $\left.\mathrm{cm}^{-2}\right]$.

Compressibility of knitted fabrics was calculated according to following expression:

$C=\frac{h_{0}-h_{m}}{h_{0}}$

where:
C- compressibility [-],

$h_{0}$ - thickness determined at a compressive load of $0.490 \mathrm{cN} \mathrm{cm}^{-2}[\mathrm{~mm}]$,

$h_{m}$ - thickness determined at a compressive load of $49.035 \mathrm{cN} \mathrm{cm}^{-2}[\mathrm{~mm}]$.

Specific volume of knitted fabrics was calculated according to following expression:

$V_{s v}=\frac{h_{0}}{W}$

where:

$V_{s v}$ - specific volume $\left[\mathrm{cm}^{3} \mathrm{~g}^{-1}\right]$,

$h_{0}$ - thickness determined at a compressive load of $0.490 \mathrm{cN} \mathrm{cm}^{-2}$ [cm].

$W$ - area density $\left[\mathrm{g} \mathrm{cm}^{-2}\right]$,

\section{Results and discussion}

The results of the investigation are given in the form of alterations in the following compression properties: thickness $\left(h_{0}\right.$ and $\left.h_{m}\right)$, compressibility $(C)$, compressional energy $(W C)$, the linearity of compression $(L C)$, compressional resilience $(R C)$ and the specific volume of knitted fabrics $\left(V_{s v}\right)$. In addition, a graphical representation of the dependence of individual compression parameters of certain structural and compressional parameters is given.

The results of the thickness of knitted fabrics measured at two different compressional loads are presented in Figure 1.

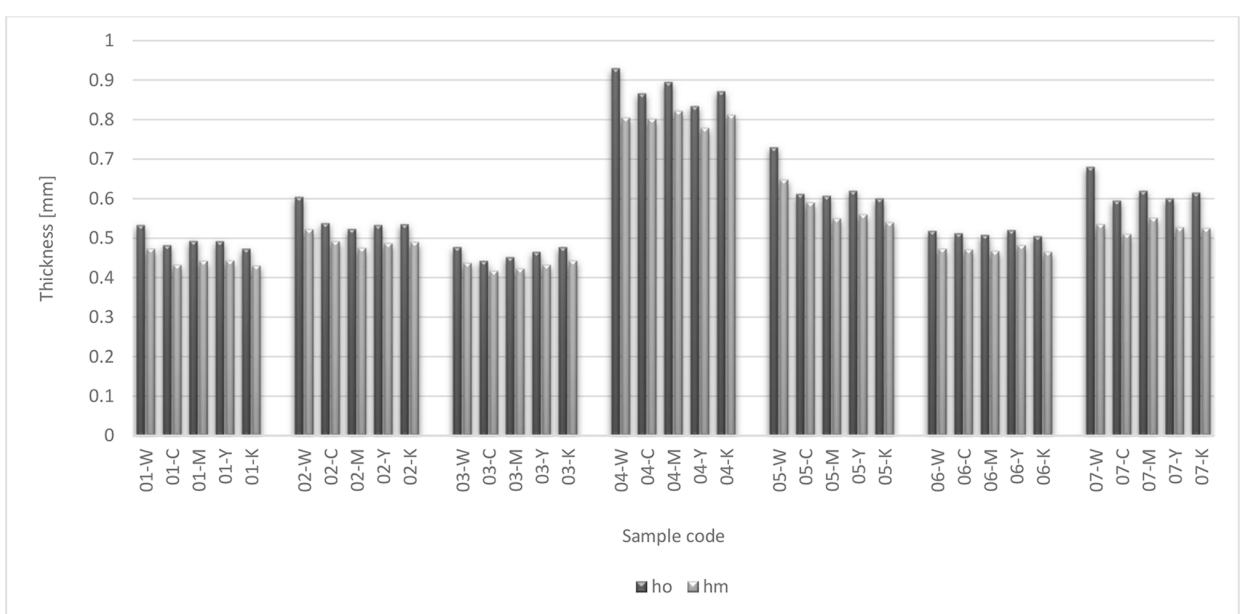

Figure 1. The thickness of knitted fabrics measured at different compressional loads

As can be seen from the results shown in Figure 1, with the increase of compression load the thickness of both unprinted and printed knitted fabrics also decreases. A decrease in both $h_{0}$ and $h_{m}$ thicknesses was observed after the application of sublimation printing, which is a consequence of the application of pressure in the heat press during the ink curing process. In PES printed knitted fabrics, a slight decrease in $h_{m}$ thickness was observed in relation to $h_{0}$, while in this case of Co/PES and Co knitted fabrics decrease of $h_{m}$ values is more pronounced.

The results of $W C$ and $L C$ of knitted fabrics are presented in Figure 2. 


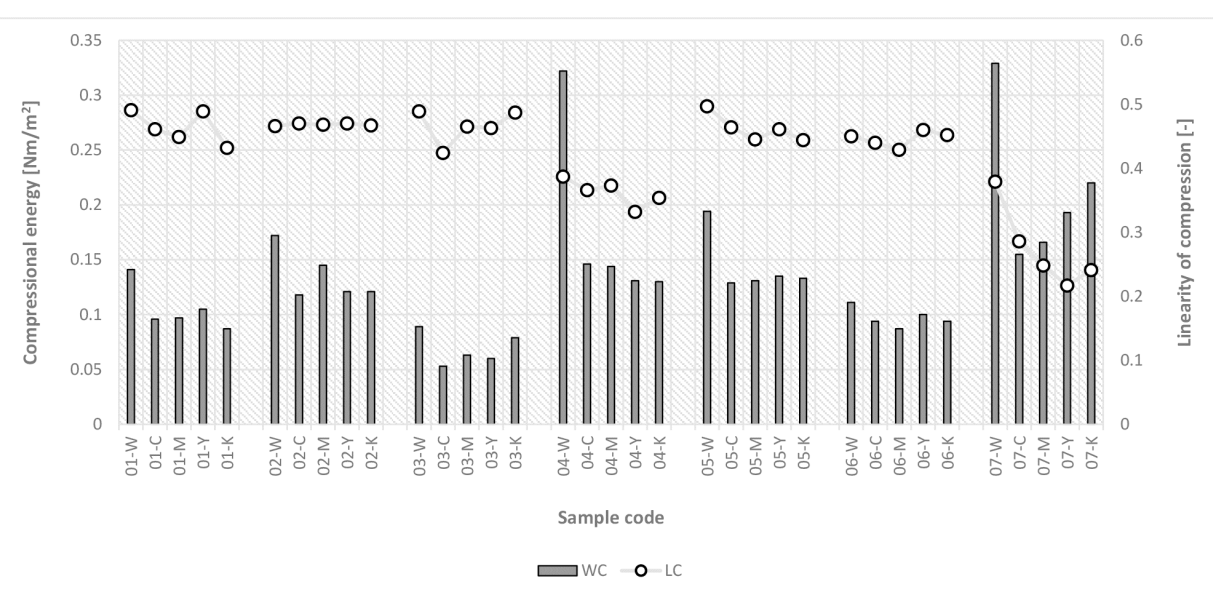

Figure 2. Compressional energy and linearity of compression of analysed knitted fabrics

A decrease of $W C$ values was recorded for all knitted fabrics samples after the printing process. For unprinted samples, the highest $W C$ values were recorded for Co $\left(0.322 \mathrm{Nm} / \mathrm{m}^{2}\right)$ and Co/PES $\left(0.329 \mathrm{Nm} / \mathrm{m}^{2}\right) \mathrm{knitted}$ fabrics, but after the application of the printing process, there is a significant decrease in these values. For $\mathrm{Co} /$ PES knitted fabrics in pique pattern decrease ranging from $54.66 \%$ to $59.63 \%$ was recorded for WC values while a decrease ranging from $33.13 \%$ to $52.89 \%$ was recorded for Co knitted fabrics in plain jersey pattern.

The lowest reduction percentage of WC values (from $15.32 \%$ to $21.62 \%$ ) was recorded for knitted fabrics in rib knit pattern with sample code 06 . This knitted fabric was knitted by using the yarn of the highest linear density (11.11 tex) and have the highest weight in comparison to other PES knitted fabrics. In addition, this knitted fabric has high total density value (279.0). All these factors contributed to the stable structure of this knitted fabric on which compression load had the smallest impact after the printing process.

For knitted fabrics with sample code 01,02 and 05 (made using the same yarn 7.40 tex) it can be concluded that the $W C$ values increase with the thickness increase of the knitted fabrics. If the results of obtained WC values for interlock knitted fabrics are analysed, it can be seen that the values of the WC are dependent on the thickness of the knitted fabrics, which can be also seen from the results shown in Figure 2.

The decrease in $W C$ values indicates that all knitted fabric samples had a decrease in fullness and volume after application of the printing process. This is a consequence of the curing process, i.e., using the pressure and heat in a heat press.

Based on the analysis of the results shown in Figure 2 , it is evident that for PES samples there were slight changes in the $L C$ values after the printing process. In the case of knitted fabrics in interlock pattern decrease in the $L C$ values from $0.41 \%$ to $12.02 \%$ for knitted fabrics with sample code 01 and from $0.41 \%$ to $13.29 \%$ for knitted fabrics with sample code 03 was recorded. While, for knitted fabrics with sample code 02 , insignificant change in $L C$ values was recorded.

For PES knitted fabrics in honeycomb pattern with sample code 05 decrease in $L C$ values ranging from $7.24 \%$ to $10.46 \%$ was recorded. Prior to the application of the printing process, higher $L C$ values were observed for PES (from 0.45 to 0.497 ) knitted fabrics compared to Co/PES (0.387) and Co (0.379) knitted fabrics. For Co/ PES knitted fabrics with sample code 04 a decrease in $L C$ values in the range from $3.62 \%$ to $14.21 \%$ was recorded after the printing process. In the case of Co knitted fabrics in plain jersey pattern with 07 sample code, there was a decrease in the $L C$ value after the printing process, which varied from $24.54 \%$ to $42.74 \%$.

Dependence of $W C$ of $h_{0}$ and $h_{m}$ thicknesses for PES knitted fabrics are presented in Figure 3.

a)

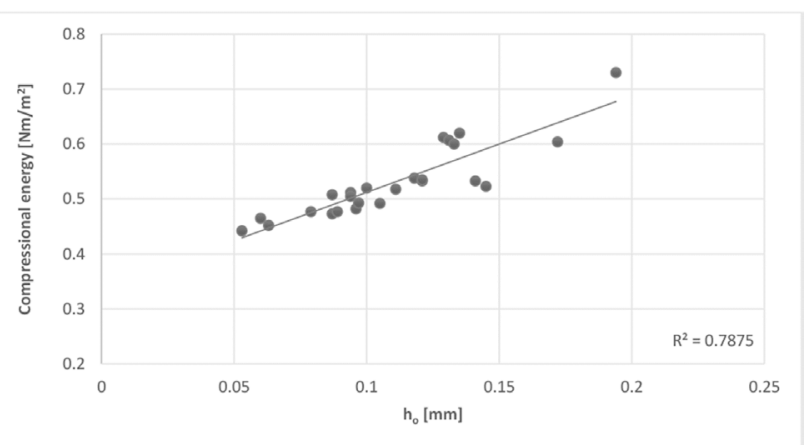

b)

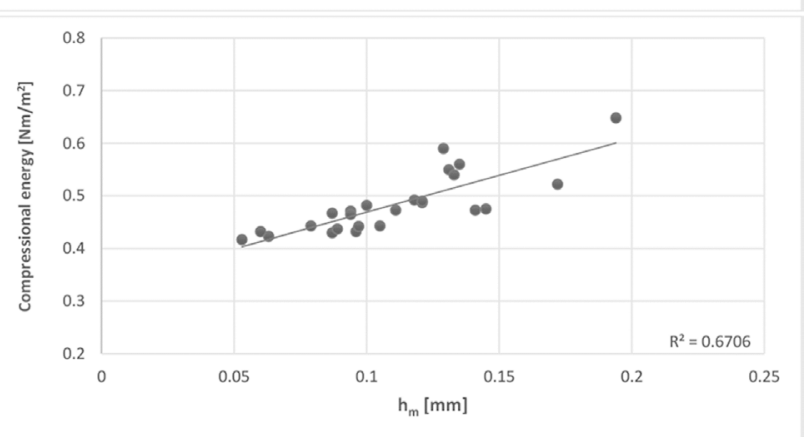

Figure 3. Dependence of compressional energy of a) thickness $h_{0}$ and b) thickness $h_{m}$ for PES knitted fabrics 


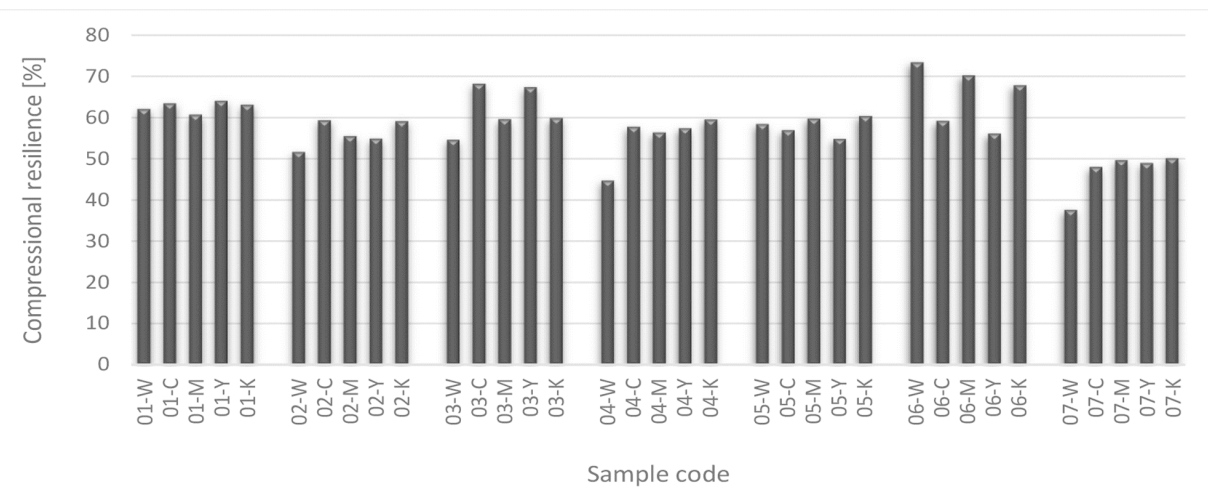

Figure 4. Compressional resilience of analysed knitted fabric

Based on the results shown in Figure 3, it can be consulted that the dependencies between WC and thickness $h_{0}$ for PES knitted fabrics is high in terms of the functional dependence which is indicated by the high value of $R^{2}(0.7875)$ while, for dependence between WC and thickness $h_{m}$ obtained value of $R^{2}$ was 0.6706 .

The $R C$ results of analysed knitted fabrics are presented in Figure 4.

As can be seen from Figure 4, higher $R C$ results were obtained for PES knitted fabrics (from $51.60 \%$ to $73.38 \%$ ) in comparison to Co/PES (from $44.63 \%$ to $59.46 \%$ ) and Co (from $37.48 \%$ to $50.05 \%$ ) knitted fabrics. For PES knitted fabrics with sample codes 01,02 and 05 , which were knitted using the same yarn $(7.40$ tex), a slight change in $R C$ values was recorded after the printing process, while for knitted fabrics in interlock pattern with sample code 03 increase ranging from $5.02 \%$ to $13.61 \%$ was recorded.

a)

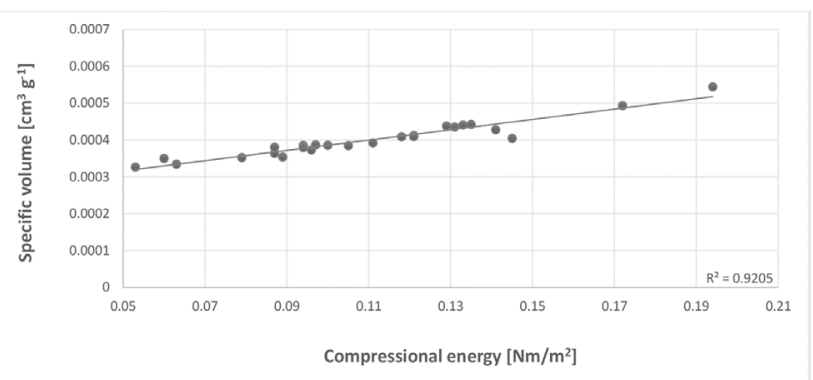

b)

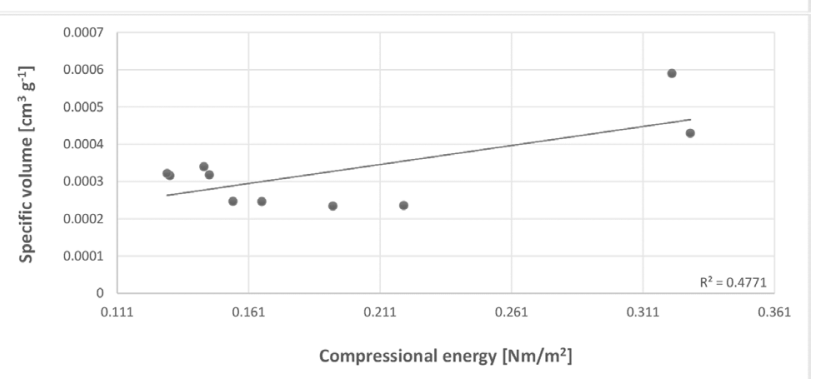

Figure 5. Dependence of specific volume of compressional energy a) for PES knitted fabrics and b) for Co and Co/PES knitted fabrics
A more pronounced change in $R C$ values was observed for Co/PES and Co knitted fabrics after the printing process. For Co/PES knitted fabrics in pique pattern with sample code 04 increase of $R C$ values, ranging from $1.67 \%$ to $14.83 \%$ was recorded. In addition, for Co knitted fabrics with sample code 07 increase ranging from $2.11 \%$ to $10.43 \%$ was recorded for $R C$ values after the printing process. The obtained results can be explained by the change in the structure of the knitted fabrics, which was the consequence of the modification.

Higher RC values give a softer, fuller, and smoother feel of textile material.

In Figure $5 a$, the dependence of $V_{s v}$ of WC for PES knitted fabrics, while in Figure 5b, these results for $\mathrm{Co} /$ PES and Co knitted fabrics are presented.

Based on the results shown in Figure $5 a$, it can be noticed that the dependencies of $V_{s V}$ of $W C$ for PES knitted fabrics are quite satisfactory in terms of the functional dependence, which can be confirmed by $R^{2}$ value (0.9205). In addition, dependencies between $V_{s v}$ and $W C$ for Co and Co/PES knitted fabrics (Figure $5 \mathrm{~b}$ ) are low in terms of functional dependence, which was confirmed by the $R^{2}$ value of 0.477 . This can be explained by the modification process, i.e., the use of sublimation powder created a surface layer on knitted fabrics, which reduced the elasticity, increased rigidity, and contributed to the reduction of $V_{S V}$ and $W C$ values of these knitted fabrics.

The results of $V_{s v}$ and $C$ of knitted fabrics are presented in Figure 6.

It is visible in Figure 6 that $C$ and $V_{s v}$ values decrease after the printing process for all knitted fabrics. For PES knitted fabrics in interlock pattern with sample code 01 decrease in compressibility values range from $7.96 \%$ to $19.47 \%$, for knitted fabrics with sample code 02 a decrease ranging from $32.35 \%$ to $38.24 \%$ while for knitted fabrics with sample code 03 a decrease ranging from $15.48 \%$ to $32.14 \%$ was recorded. For knitted fabrics in pique pattern with sample code 05 decrease ranging from $10.71 \%$ to $30.36 \%$ was recorded for $C$ values after the printing process. The smallest influence of the printing process on $C$ values was recorded for knitted fabrics in rib knit pattern with sample code 06. For this 
printed samples, the smallest decrease in $C$ values was recorded, ranging from $6.90 \%$ to $16.09 \%$. These results correspond to both $W C$ and $L C$ results obtained for the knitted fabrics in rib knit pattern with sample code 06.

The modification process significantly influenced the results of compressibility. Unprinted Co/PES (0.134) and Co $(0.213)$ knitted fabrics have significantly high $C$ values. The percentage of compressibility reduction was much higher for $\mathrm{Co}$ and Co/PES printed knitted fabric in comparison to PES printed knitted fabrics. For Co/PES knitted fabrics in pique pattern decrease ranging from $38.81 \%$ to $50.75 \%$ was recorded while for Co printed knitted fabrics in plain jersey pattern decrease in $C$ values range from $34.46 \%$ to $47.89 \%$. Such a significant reduction in $C$ values has a negative impact on the fabrics hand.

For knitted fabrics in interlock pattern $(01,02$ and 03 sample code), the factor which influenced the reduction of $V_{s v}$ values the most is the yarn parameters. The smallest reduction in $V_{s v}$ values was observed for knitted fabrics with sample code 03 . This knitted fabric was knitted using two yarns that contributed to the improved stability of the structure which was least affected by the compres- sion load. If results of $V_{s v}$ for knitted fabrics with sample codes 01 and 02 that are made of the same yarn and in the same pattern are analysed, it can be concluded that the percentage decrease in $V_{s v}$ value depends on the density and weight of knitted fabrics.

The smallest change in $V_{s v}$ values after the application of sublimation printing was recorded for PES knitted fabrics in rib knit pattern with the sample code 06. This knitted fabric was knitted using the yarn of highest linear density (11.11 tex) in comparison to other PES knitted fabrics. The obtained $V_{s v}$ results correspond to other results of compression properties obtained for this knitted fabric.

A smaller decrease in $V_{s v}$ values was observed in PES knitted fabrics compared to Co and Co/PES knitted fabrics after the printing process. For Co/PES knitted fabrics with sample code 04, there was a decrease in $V_{s v}$ values ranging from $42.37 \%$ to $45.76 \%$ while a decrease ranging from $41.86 \%$ to $44.19 \%$ was recorded for Co printed knitted fabrics with sample code 07 after the printing process. This can be explained by modification process.

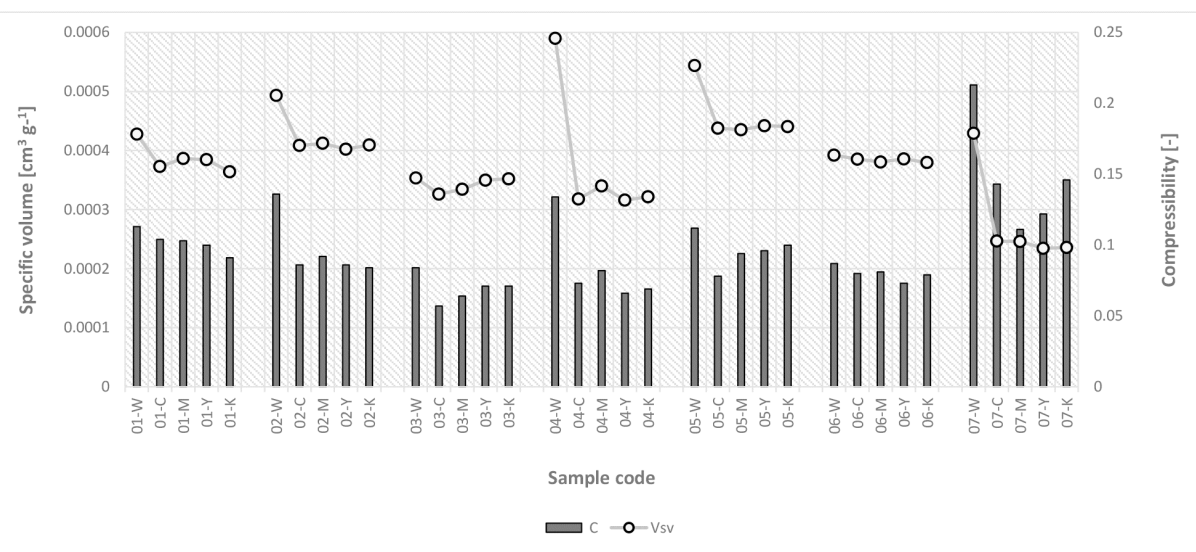

Figure 6. Specific volume and compressibility of analysed knitted fabrics

Dependence of $C$ on weight for PES knitted fabrics in interlock pattern is presented in Figure 7.

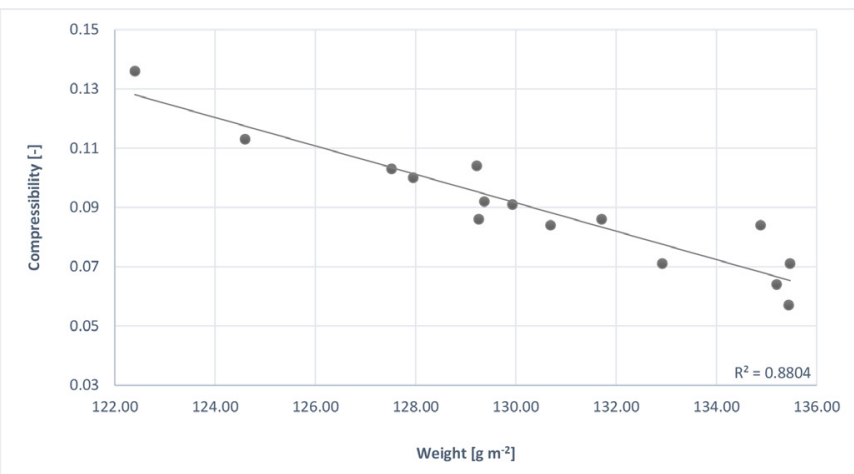

Figure 7. Dependence of compressibility of weight for PES knitted fabrics in interlock pattern

As it can be seen from Figure 7, high dependencies of compressibility of weight for PES knitted fabrics in in- terlock pattern was observed, which is also visible from obtained $R^{2}$ value of 0.8804 .

\section{Conclusion}

In this study, the change of compression properties of seven different knitted fabrics that differs in raw material, pattern, yarn parameters, weight, and densities, after the sublimation printing process was investigated. The modification process was required when printing $\mathrm{Co}$ and $\mathrm{Co} /$ PES knitted fabrics with the aim of binding the disperse dyes to the natural fibres which has greatly contributed to the change of compression properties.

During the curing process in the heat press, i.e., exposure knitted fabrics to heat and compression pressure, following changes occurred in PES knitted fabrics:

Reduction of thicknesses $\left(h_{0}\right.$ and $\left.h_{m}\right)$ and deformation of the structure, which further affected the other compression properties of knitted fabrics; 
- $\quad$ Slight decrease in $W C$ values and insignificant change in $R C$ values for knitted fabrics with sample code 01 and 05 , while for knitted fabrics 02 small increase in $R C$ values was detected;

- $\quad$ Slight decrease in $L C$ values;

- $\quad$ Small decrease in $C$ and $V_{S V}$ values. Good dependence between $C$ and weight for PES knitted fabrics in interlock pattern was established.

The PES knitted fabric on which the printing process had the least influence on the change of compression properties was a knitted fabric in a rip knit pattern with sample code 06 . This can be explained by the fact that this knitted fabric was made using yarn of highest linear density (11.11 tex) as well as that poses the highest weight compared to other PES knitted fabrics.

The use of sublimation coating powder contributed to the change in the structure of $\mathrm{Co}$ and Co/PES knitted fabrics. This resulted in structure alteration, powder and dye were incorporated into the pores and fibres, which created a layer on the surface of the knitted fabrics. Because of these alterations, the following changes occurs in compression properties of Co/PES and Co knitted fabrics:

- $\quad$ Significant decrease of $W C$ values;

- $\quad$ Increase of $R C$ values;

- $\quad$ Large decrease of $C$ and $V_{s V}$ values. This can be explained by the modification process, i.e., the application of sublimation coating powder, which changed the structure and contributed to the reduction of the thickness $\left(h_{0}\right.$ and $\left.h_{m}\right)$ of these knitted fabrics.

The obtained result indicates that the printing process had less impact on the PES knitted fabric compared to Co and Co/PES knitted fabrics compression properties. For all knitted fabrics samples a decrease in fullness and specific volume after application of printing process was recorded in to varying degrees.

A deeper understanding of compressional properties of knitted fabrics printed by sublimating printing technique can be very beneficial to engineers who are designing printed knitted fabrics for sportswear manufacturing.

\section{Acknowledgements}

Central European Exchange Program for University Studies, Grant/Award Number: 2018-0589-99 and 20190347-99.

\section{References}

[1] J. Geršak, Objektivno vrednovanje plošnih tekstilija i odjeće. Sveučilište u Zagrebu Tekstilno-Tehnološki fakultet, Zagreb, 2014, p.102.

[2] Murthyguru, Novel approach to study compression properties in textiles, Autex Research Journal, 5(4) (2005) 176-193.

[3] M. Matsudaira, H. Qin, Features and Mechanical Parameters of a Fabric's Compressional Property, Journal of the Textile Institute, 86(3) (1995) 476-486.
[4] M. Maqsood, Y. Nawab, J. Umar, M. Umair, K. Shaker, Comparison of compression properties of stretchable knitted fabrics and bi-stretch woven fabrics for compression garments, The Journal of The Textile Institute, 108(4) (2017) 522-527.

[5] D. Alimaa, T. Matsuo, M. Nakajima, M. Takahashi, E. Yamada, Pressure thickness relation and compression mechanism of plain and rib knitted fabrics, Journal of Textile Machinery Society of Japan (English Edition), 46(1) (2000) 7-10.

[6] T. Matsuo, M. Takahashi, M, Nakajima, Compression of Plain Knitted Fabrics Predicted from Yam Properties and Fabric Geometry. Textile Research Journal, 73 (10) (2003) 861-866.

[7] M. Bakhtiari, S. Shaikhzadeh Najar, S. M. Etrati, Z. Khorram Toosi, Compression properties of weft knitted fabrics consisting of shrinkable and non-shrinkable acrylic fibers, Fibers and Polymers, 7 (2006) 295-304.

[8] M-S. Choi, S.P. Ashdown, Effect of Changes in Knit Structure and Density on the Mechanical and Hand Properties of Weft-Knitted Fabrics for Outerwear, Textile Research Journal, 70(12) (2000) 1033-1045.

[9] J. Geršak, Development of the system for qualitative prediction of garments appearance, International Journal of Clothing Science and Technology, 14(3/4) (2002) 169180.

[10] G. Gunasekaran, C. V. Koushik, V. Subramaniam, T. Ramachandran, Evaluation of a new single parameter for characterising the compressional properties of weft-knitted fabrics, Indian Journal of Fibre and Textile Research, 36 (3) (2011) 242-247.

[11] ISO 5084:1996. Textiles - Determination of thickness of textiles and textile products.

[12] ISO 139:2005. Textiles - Standard atmospheres for conditioning and testing.

[13] Kato Tech Co Ltd., Operating instrument KES-FB3 AUTO - A: Compression tester. Kyoto, 1998. 
Izvod

\section{KOMPRESIJSKA SVOJSTVA PLETENINA ŠTAMPANIH TEHNIKOM SUBLIMACIONE TRANSFER ŠTAMPE}

Sandra Stojanović1, Jelka Geršak², Dušan Trajković1

\footnotetext{
${ }^{1}$ Tehnološki fakultet, Leskovac, Srbija

2Istraživačko-inovacijski centar za dizajn i odevni inženjering, Mašinski faklutet, Univerzitet u Mariboru, Maribor, Slovenija (Raziskovalno-inovacijski center za design in oblačilno inženirstvo, Fakulteta za strojništvo Univerza v Mariboru, Maribor, Slovenija)
}

Kompresijska svojstva su korisna pri određivanju punoće, mekoće, glatkoće i krutosti tekstilnih materijala. Pored toga, parametri kompresije imaju značajan uticaj na vrednosti opipa i kvalitet tekstilnih materijala. Ovaj rad izveštava o uticaju procesa sublimacijske transfer štampe na promenu kompresijskih svojstava pletenina (poliestar, pamuk i pamuk/poliestar) namenjenih za izradu sportske odeće. U tu svrhu korišćen je KES-FB3-A Compression Tester za merenje parametara kompresijskih svojstava. Parametri koji su doprineli najmanjem procentu smanjenja kompresijskih svojstava kod poliestarskih pletenina su površinska masa i podužna masa pređe. Za pletenine koje sadrže pamučna vlakna korišćen je sublimacijski prah za modifikaciju papira s ciljem vezivanja disperznih boja za ova vlakna. Analiza rezultata pokazala je da je postupak štampe imao manji uticaj na promenu kompresijskih parametara poliestarskih u odnosu na pamučne i pletenine iz mešavine poliestarskih i pamučnih vlakana. Primećeno je da je postupak štampe uticao na smanjenje debljine svih pletenina u različitom stepenu. Postupak štampe doprineo je malom smanjenju kompresibilnosti i vrednosti specifičnih zapremina poliestarskih pletenina. Proces modifikacije doprineo je značajnom smanjenju kompresibilnosti pamučnih (od $34.46 \%$ do $47.89 \%$ ) i pletenina iz mešavine poliestarskih i pamučnih vlakana (od $38.81 \%$ do $50.75 \%$ ). Pored toga, smanjenje vrednosti specifične zapremine kreće se od $41.86 \%$ do $44.19 \%$ za pamučne i od $42.37 \%$ do $45.75 \%$ za pletenine iz mešavine poliestarskih i pamučnih vlakana.
(ORIGINALNI NAUČNI RAD) UDK 677.075:677.027.55 DOI 10.5937/savteh2101046S . Ključne reči: pletenine, kompresijska
svojstva, sublimaciona štampa, postupak modifikacije, pamuk i poliestar 